\title{
Growth performance and beef quality of Xinjiang brown cattle fed with different dosages of selenized yeast
}

\author{
Zhichun $\mathrm{Li}^{\mathrm{a}}{ }^{\mathrm{d}, *}$, Jian Sun ${ }^{\mathrm{a}, \mathrm{d}}$, Jiazhou Wei ${ }^{\mathrm{c}}$, Hock Eng Khoo ${ }^{\mathrm{b}}$, Zhijian $\mathrm{Wei}^{\mathrm{c}}$, Ruibo $\mathrm{Mo}^{\mathrm{c}}$ \\ a Agro-food Science and Technology Research Institute, Guangxi Academy of Agricultural Sciences, \\ Nanning 530007 China \\ b College of Chemistry and Bioengineering, Guilin University of Technology, Guilin 541006 China \\ c Guangxi State Farm Jinguang Dairy Co., Ltd., Nanning 530007 China \\ d Guangxi Key Laboratory of Fruits and Vegetables Storage-processing Technology, Nanning 530007 China
}

*Corresponding author, e-mail: lizhichun@gxaas.net

Received 8 Jan 2021

Accepted 7 Sep 2021

\begin{abstract}
The effects of different doses of selenized yeast on growth performance and beef quality of Xinjiang brown cattle were determined. Healthy Xinjiang brown cattle were divided randomly into five experimental groups. They were fed with yeast containing different doses of selenium. The body weight (BW), organ weight, and selenium content of beef samples from the muscles and organs of the cattle were measured. Physicochemical parameters and nutritional values of the longissimus dorsi muscle sample were also determined. The results showed that selenized yeast-fed cattle had reduced weight gain compared with the cattle from the control group. The beef samples of different body parts and organs of the selenized yeast-fed cattle exhibited significantly higher selenium content than the control cattle. The selenium supplementation improved the beef quality by increasing water holding capacity. It also reduced the percentages of water loss and shear force. The beef samples of the cattle fed with the highest dosage of selenized yeast contained the lowest crude protein content. The total essential amino acids of the beef samples of the supplemented cattle were significantly higher than the control cattle. The selenized yeast supplementation was also found to improve the fatty acid composition of the beef samples. The addition of selenized yeast in feed improved the beef quality of Xinjiang brown cattle. The recommended dose of selenized yeast for cattle feeds was $0.9 \mathrm{mg} / \mathrm{kg}$ BW.
\end{abstract}

KEYWORDS: Bos taurus, fatty acid methyl esters, umami taste, selenized yeast, Xinjiang brown cattle

\section{INTRODUCTION}

Xinjiang brown cattle breed, locally known as He Brow, is a new hybrid of brown cow originated from Xinjiang, China. It is one of the species from Bovidae family with the scientific name Bos taurus. This species presents a good appearance, meat quality, and growth rate [1]. Eighteen-month-old Xinjiang brown cattle have average body weight and body height of $381.43 \pm 31.26 \mathrm{~kg}$ and $117.53 \pm 3.79 \mathrm{~cm}$, respectively [2]. Recently, Xinjiang brown cattle have successfully replaced local yellow cattle for meat production in the beef industry. It is considered another type of premium due to its beef quality. The price (per kilogram) of raw Xinjiang brown cattle fresh beef is USD1-2 higher than the commercially available raw beef.

Several factors are known to affect animal meat quality. On top of the cattle variety, age, gender, and nutritional factors, different feeding methods influence the senses and intrinsic qualities of the animal meat [3]. The quality, fatty acids content, and other nutritional values of animal meat produced were varied by different feeding systems [4]. Increased intake of protein-rich diet by cattle improved their reproductive performance [5]. Besides macronutrients, supplementation of micronutrients (such as trace elements) significantly affected the meat quality $[6,7]$.

Selenium (Se) is an indispensable trace element for maintaining normal animal growth. It possesses very good bioactivities. Selenium plays an important role in promoting animal growth, enhancing the antioxidant status, and improving meat quality [6]. It also affects the body's endocrine function. Many studies have been performed to determine the production performance and meat quality of animals fed with different selenium sources and 
doses. Incorporation of Se into animal feeds also enhanced antioxidant capacity and improved meat quality even during prolonged storage [8]. An adequate amount of selenium added in feed also promoted the health of cattle [9].

As the size of cattle is large, the concentration of selenium in the feed may have a particular impact on the cow's health. The amount of selenium in cattle feeds also affects animal health and beef quality. Therefore, this study aimed to determine the effects of different selenium doses on growth performance and beef quality of Xinjiang brown cattle, as well as the optimal amount of selenium added to the cattle feed.

\section{MATERIALS AND METHODS}

\section{Preparation of animal feed}

The basic diet for the cattle was formulated according to the recommended standard (NY/T 815-2004) from the Chinese Ministry of Agriculture [10]. The selenium-enriched diets for the five groups of cattle: control (CG), A, B, C, and D, were prepared by mixing the grass silage with selenized yeast at 0 , $0.3,0.6,0.9$, and $1.2 \mathrm{mg} / \mathrm{kg} \mathrm{BW}$, respectively. The selenized yeast was purchased from Anqi Yeast Co. (Yichang, Hubei, China). The selenium dosages were calculated by following the experimental requirement. Nutritional parameters of the experimental animal's diet were shown in Table S1.

\section{Animal experimentation}

The experiment was performed on a cattle farm in Guangxi after obtained approval from the Animal Care and Use Committee of Guangxi Academy of Agricultural Sciences (approval number: GXAAS/AEEIF/00002). The healthy 30-month-old Xinjiang brown cattle were sponsored by the farm owner. Cattle of similar initial body weight (BW) between $319 \mathrm{~kg}$ and $405 \mathrm{~kg}$ were chosen. The study was done in the late summer of 2019.

Before the experiment was scheduled, 25 experimental cattle were fed with a grass silage diet. They were divided into five experimental groups: control (CG) and four selenized yeast-fed A, B, C, and D. Each experimental group consisted of five cattle. They were numbered and labeled, and the intestinal parasites were cleared before commencing the supplementation. The cattle barn was also disinfected before the experiment, and cleaned daily during the experiment. Besides, all cattle were acclimatized for seven days before the experiment to observe their behaviors and mental state. Groups A-D were fed for 90 days with $3.0 \mathrm{~kg}$ of selenium-enriched diet plus grass silage diet and tap water ad libitum daily. The leftover food was collected and recorded daily.

After the supplementation, all fasting cattle were slaughtered following standard procedure. Internal organs were removed, and different parts of beef samples were collected for measurement of selenium contents. The longest muscle between 12th and 13th ribs was obtained as a longissimus dorsi muscle sample for determination of physicochemical characteristics and nutrition compositions. Beef muscle samples were kept for $24 \mathrm{~h}$ at $4^{\circ} \mathrm{C}$ to reduce toxin accumulation. All beef samples were stored at $-80^{\circ} \mathrm{C}$ for further analyses.

\section{Determination of growth performance}

BW of each cattle was weighed at the baseline and the end of the experiment. An average daily growth rate was calculated. The daily amounts of diet given and the leftovers were weighed, the average daily food intake was measured, and the food intake to weight gain ratio was calculated. The average daily weight gain of the cattle was also determined.

\section{Physicochemical parameters of beef samples}

Quality parameters of beef samples, including $\mathrm{pH}$ value, moisture content, water holding capacity, water loss rate, cook loss rate, shear force, and color values, were determined in the present study. The $\mathrm{pH}$ values were measured using a $\mathrm{pH}$ meter (ATAGO Co., Tokyo, Japan) according to GB/T 9695.5-2008. Color values were measured according to the "beef quality grading standard" (NY/T 676-2010). The luminance (L), redness (a), and yellowness (b) values were determined using a NR20XE Precision Colorimeter (Shenzhen Threenh Technology Co., Shenzhen, Guangdong, China). Water holding capacity, water loss rate, cook loss rate, and shear force values were measured in five replicates.

\section{Nutritional composition of beef samples}

Dry matter, crude protein, and crude fat in beef samples were determined according to GB 5009.32010, GB 5009.5-2010, and GB 5009.6-2003, respectively. Amino acid composition of the beef samples was determined according to GB 5009.1242016 [11]. Briefly, the beef sample was pulverized and then homogenized. Each homogenized sample was added with $10 \mathrm{ml}$ of $6 \mathrm{M}$ hydrochloric acid solution and four drops of phenol solution. The tube was placed in a hydrolysis furnace at $110 \pm 1{ }^{\circ} \mathrm{C}$ for $22 \mathrm{~h}$. The hydrolysates were then filtered and dried under reduced pressure. The dried residue was 
dissolved in a $1.0 \mathrm{ml}$ citrate buffer solution ( $\mathrm{pH}$ 2.2) and filtered.

HPLC quantification of amino acids was performed using a Hitachi L-8800 amino acid analyzer (Tokyo, Japan). The separation of amino acids was achieved using an analytical column $(4.6 \mathrm{~mm} \times 60 \mathrm{~mm}, 3 \mu \mathrm{m})$. The reactor temperature was set at $135^{\circ} \mathrm{C}$, the column temperature was $57^{\circ} \mathrm{C}$, and the sample injection volume was $20 \mu 1$. The flow rates of pumps 1 and 2 were 0.40 and $0.35 \mathrm{ml} / \mathrm{min}$, and the detection wavelengths of the first and the second channels were $570 \mathrm{~nm}$ and $440 \mathrm{~nm}$, respectively. The sequential elution was $32 \mathrm{~min}$, and the total run time was $53 \mathrm{~min}$. The doses of the amino acids were calculated based on external standards.

In brief, beef fat was extracted with petroleum ether three times before preparing fatty acid methyl esters (FAMEs). FAMEs were prepared according to a previously described procedure [12]. The extracted fat $(1.0 \mathrm{~g})$ was weighed and added with $8 \mathrm{ml}$ of methanol containing $2 \%$ sodium hydroxide in a test tube. The tube was then heated in a water bath at $80^{\circ} \mathrm{C}$ for $5 \mathrm{~min}$. After cooling, $7 \mathrm{ml}$ of methanol containing $15 \%$ boron trifluoride was added to the mixture and reheated in the water bath at $80^{\circ} \mathrm{C}$ for $2 \mathrm{~min}$. The tube was cooled to room temperature. Then, $10 \mathrm{ml}$ of $\mathrm{n}$-heptane was added and agitated for 2 min before adding saturated sodium chloride solution.

Fatty acids were analyzed according to the method described in GB 5009.168-2016 [12]. An Agilent 7890A gas chromatography (Agilent Corporation, Santa Clara, CA, USA) was used to quantify fatty acid contents. TR-FAME GC column $(100 \mathrm{~m} \times 0.25 \mathrm{~mm} \times 0.2 \mu \mathrm{m})$ was used for fatty acids separation. The flow rate of nitrogen was $1.0 \mathrm{ml} / \mathrm{min}$, and the injector temperature was $270^{\circ} \mathrm{C}$. The ion source temperature was set at $280^{\circ} \mathrm{C}$, whereas the interface temperature was set at $230^{\circ} \mathrm{C}$. FAME standard was dissolved in methanol at a concentration of $5.0 \mathrm{mg} / \mathrm{ml}$.

\section{Quantification of selenium}

All beef samples were pre-treated before the analysis of selenium. Briefly, $2.0 \mathrm{~g}$ of beef sample was homogenized with $10 \mathrm{ml}$ of distilled water. Then, $10 \mathrm{ml}$ of digestion reagent (containing $9 \mathrm{ml}$ of nitric acid and $1 \mathrm{ml}$ of perchloric acid) was added. The mixture was kept overnight and heated on a hotplate until the solution became clear and colorless. The digested solution was cooled to room temperature, and $2.5 \mathrm{ml}$ of $6 \mathrm{M}$ hydrochloric acid solution was added to further digest the sample. The fully digested solution was used for selenium analysis. The analysis was performed using an AFS9700 atomic fluorescence spectrometer (Beijing, China) according to the slightly modified method described in the literature [13]. A stock solution of 1000 ppm selenium (Sigma-Aldrich Trading Co., Ltd., Shanghai, China) was used as a calibration standard. Selenium content of the sample was expressed as $\mathrm{mg} / \mathrm{kg}$.

\section{Statistical analysis}

All data were presented as mean \pm standard error of the mean (SEM) with five replicates. Mean differences were analyzed using IBM SPSS Statistics version 23 for Windows. A least significant difference (LSD) multiple comparisons were performed to determine differences between different experimental groups. Pearson correlation analysis was used to determine the correlation between selenium doses in the feed and beef selenium levels. The significant changes were determined statistically for all variables $(p<0.05)$.

\section{RESULTS AND DISCUSSION \\ Effects of different selenium doses on growth performance}

Selenium is a trace element that affects cow growth [9]. As shown in Table 1, there were significant differences $(p<0.05)$ for the average daily weight gain (ADWG) among different selenized yeast-fed cattle groups. The ADWG values of cattle from groups A-D were significantly lower than the control group $(p<0.05)$. The weight gain of the cattle fed with different doses of the selenized yeast was not significantly different $(p>$ 0.05), except for the group B cattle. Moreover, the average daily food intake (ADFI) of all groups was similar. Also, all supplemented cattle had F/G ratios significantly higher than the control cattle. The finding suggested that the selenized yeast-fed cattle had increased metabolism rate and thus reduced weight gain.

In this study, selenized yeast-fed cattle significantly varied in weight gain (Table 1), particularly in the cattle supplemented with $0.6 \mathrm{mg} / \mathrm{kg}$ selenized yeast. The supplementation significantly reduced the BWs of the experimental cattle. The weight loss might be due to the higher metabolic rate of selenium supplemented cattle. Selenium promotes animal growth by increasing cellular stress and glutathione peroxidase levels. It also increases 
Table 1 Effects of diet with different selenium doses on growth performance of Xinjiang brown cattle.

\begin{tabular}{lccccc}
\hline Group & $\begin{array}{c}\text { Initial BW } \\
(\mathrm{kg})\end{array}$ & $\begin{array}{c}\text { Final BW } \\
(\mathrm{kg})\end{array}$ & $\begin{array}{c}\text { Average daily weight gain } \\
(\mathrm{kg} / \text { day) }\end{array}$ & $\begin{array}{c}\text { Average daily food intake } \\
(\mathrm{kg} / \text { day })\end{array}$ & F/G \\
\hline CG & $362.67 \pm 9.75^{\mathrm{d}}$ & $415.83 \pm 8.26^{\mathrm{a}}$ & $0.59 \pm 10.97^{\mathrm{a}}$ & $27.93 \pm 3.42^{\mathrm{a}}$ & $0.47 \pm 0.07^{\mathrm{e}}$ \\
A & $373.67 \pm 5.86^{\mathrm{b}}$ & $404.33 \pm 9.29^{\mathrm{d}}$ & $0.34 \pm 8.50^{\mathrm{c}}$ & $27.14 \pm 2.68^{\mathrm{a}}$ & $0.80 \pm 0.04^{\mathrm{b}}$ \\
B & $345.50 \pm 8.51^{\mathrm{e}}$ & $412.00 \pm 14.27^{\mathrm{c}}$ & $0.52 \pm 5.69^{\mathrm{b}}$ & $28.09 \pm 4.78^{\mathrm{a}}$ & $0.54 \pm 0.05^{\mathrm{d}}$ \\
C & $363.50 \pm 4.50^{\mathrm{c}}$ & $393.50 \pm 15.72^{\mathrm{e}}$ & $0.33 \pm 24.83^{\mathrm{c}}$ & $28.20 \pm 3.39^{\mathrm{a}}$ & $0.85 \pm 0.06^{\mathrm{a}}$ \\
D & $383.00 \pm 9.53^{\mathrm{a}}$ & $415.33 \pm 7.45^{\mathrm{b}}$ & $0.36 \pm 8.24^{\mathrm{c}}$ & $28.23 \pm 5.77^{\mathrm{a}}$ & $0.78 \pm 0.06^{\mathrm{c}}$ \\
\hline
\end{tabular}

All data are expressed as mean \pm SEM of five replicates. Different superscript lowercase letters denote significant differences between different experimental groups $(p<0.05)$. CG is control group; A, B, C, and D are groups of experimental cattle fed with $0.3,0.6,0.9$, and $1.2 \mathrm{mg} / \mathrm{kg}$ selenized yeast, respectively. BW: body weight; F: average daily food intake; G: average daily weight gain.

the antioxidant capability to achieve a maximal growth-promoting effect. Hence, the mineral promotes the synthesis and the turnover of muscle proteins by increasing thyroid hormone to up-regulate growth hormone genes and synthesize growth hormone [14]. Therefore, a moderate amount of selenium supplement improved the growth performance of the cattle, but the effect of selenium on growth performance is varied in different studies.

Literature shows that the supplementation of selenized yeast to beef cattle improved their growth performance and health status [15]. On the contrary, a previous study reported that no significant changes were found for the carcass weight and muscles weight between the selenium supplemented fed $(65 \mu \mathrm{g} / \mathrm{kg} \mathrm{BW})$ and the non-supplemented $(9.5 \mu \mathrm{g} / \mathrm{kg} \mathrm{BW})$ beef cattle [16]. Like cattle, selenium supplementation to the experimental swine also significantly increased the selenium levels in their organs [17].

\section{Effect of different selenium levels on selenium content of beef muscles and organs}

Selenium content of beef muscles from three body parts and organs of the experimental cattle was determined (Table 2). The results showed significant differences in the selenium content in triceps brachii, longissimus dorsi, and adductor between the different experimental groups. All parts of the beef muscles of the supplementation groups contained significantly higher selenium contents than those of the control group. Selenium contents of the different parts of beef muscles were dosedependent, where $r^{2}$ values of graph for selenium in beef muscles versus selenium dosage were higher than 0.8 (Table 2). The finding shows that the higher the amount of selenium supplemented to the cattle, the higher the selenium level determined in the beef muscles. The organs (liver, heart, and kidney) obtained from the supplemented cattle con- tained significantly higher selenium levels than the control cattle. The selenium levels determined in the organ samples were dose-dependent, where the high selenium level of the organs was attributed to the increased intake of selenium from the diet. It shows that the absorption of dietary selenium by the animal's digestive system is high.

It is hypothesized that the organic selenium supplemented to the cattle is highly deposited in both muscle and liver tissues. The finding of this study is in line with the data shown in a previous study that supplementation of the experimental cattle with selenite, selenized yeast, and selenium-enriched cereals contributed to the increased selenium contents in the muscle tissues of the cattle [9]. The organic and inorganic selenium supplements increased the selenium doses of the cattle's livers [18]. Another study reported that supplementation of sodium selenite and selenium-enriched diet to the experimental cattle contributed to the increased liver selenium content [19]. On the contrary, supplementation of calcium to the cattle significantly reduced the selenium content in the muscle tissue [20]. The deposition of selenium in the muscle tissue is dependent on the type of selenium. A previous study reported that inorganic selenium is utilized for selenoprotein synthesis, whereas organic selenium is mainly deposited in the muscle tissues [9].

\section{Effect of different selenium levels on physicochemical quality of beef muscles and organs}

Table 3 shows that the physicochemical parameters, except the $\mathrm{pH}$ value, of beef muscles (meats) of the five Xinjiang brown cattle experimental groups were significantly different $(p<0.05)$. The $\mathrm{pH}$ values of the supplemented cattle beef samples were significantly lower than the control cattle $(p<0.05)$. In addition, the water holding capacity and cook loss rate of the beef samples obtained from the 
Table 2 Effects of diet with different selenium doses on selenium content $(\mathrm{mg} / \mathrm{kg})$ in various beef muscles and organs of Xinjiang brown cattle.

\begin{tabular}{lcccccc}
\hline Part & CG & A & B & C & D & $r^{2}$ \\
\hline Triceps brachii & $0.13 \pm 0.06^{\mathrm{c}}$ & $0.18 \pm 0.11^{\mathrm{b}}$ & $0.18 \pm 0.05^{\mathrm{b}}$ & $0.19 \pm 0.13^{\mathrm{b}}$ & $0.21 \pm 0.12^{\mathrm{a}}$ & 0.83 \\
Longissimus dorsi & $0.14 \pm 0.07^{\mathrm{e}}$ & $0.15 \pm 0.05^{\mathrm{d}}$ & $0.17 \pm 0.13^{\mathrm{c}}$ & $0.18 \pm 0.10^{\mathrm{b}}$ & $0.22 \pm 0.16^{\mathrm{a}}$ & 0.93 \\
Adductor & $0.11 \pm 0.03^{\mathrm{c}}$ & $0.18 \pm 0.06^{\mathrm{b}}$ & $0.18 \pm 0.03^{\mathrm{b}}$ & $0.20 \pm 0.11^{\mathrm{a}}$ & $0.21 \pm 0.08^{\mathrm{a}}$ & 0.81 \\
Liver & $0.07 \pm 0.02^{\mathrm{e}}$ & $0.13 \pm 0.08^{\mathrm{d}}$ & $0.17 \pm 0.11^{\mathrm{c}}$ & $0.18 \pm 0.05^{\mathrm{b}}$ & $0.41 \pm 0.28^{\mathrm{a}}$ & 0.80 \\
Heart & $0.21 \pm 0.05^{\mathrm{e}}$ & $0.29 \pm 0.03^{\mathrm{d}}$ & $0.39 \pm 0.21^{\mathrm{c}}$ & $0.46 \pm 0.23^{\mathrm{b}}$ & $0.48 \pm 0.25^{\mathrm{a}}$ & 0.96 \\
Kidney & $0.53 \pm 0.28^{\mathrm{e}}$ & $1.15 \pm 0.65^{\mathrm{d}}$ & $1.30 \pm 0.66^{\mathrm{c}}$ & $1.37 \pm 0.53^{\mathrm{b}}$ & $1.44 \pm 0.21^{\mathrm{a}}$ & 0.97 \\
\hline
\end{tabular}

All data are expressed as mean \pm SEM $(\mathrm{mg} / \mathrm{kg})$ of five replicates. Different superscript lowercase letters denote significant differences between different experimental groups $(p<0.05) ; r^{2}$ is the correlation between the concentration of selenium in the feed and selenium levels in the beef muscle or organ.

Table 3 Effects of diet with different selenium doses on beef quality of Xinjiang brown cattle.

\begin{tabular}{|c|c|c|c|c|c|c|}
\hline Item & CG & A & B & C & D & *Literature \\
\hline $\begin{array}{l}\text { Physicochemical } \\
\text { pH value } \\
\text { Water holding capacity (\%) } \\
\text { Water loss (\%) } \\
\text { Cook loss rate (\%) } \\
\text { Shear force (N) }\end{array}$ & $\begin{array}{r}6.80 \pm 0.05^{\mathrm{a}} \\
41.36 \pm 1.35^{\mathrm{d}} \\
42.97 \pm 1.47^{\mathrm{a}} \\
61.93 \pm 2.46^{\mathrm{d}} \\
73.48 \pm 2.73^{\mathrm{a}}\end{array}$ & $\begin{array}{r}6.60 \pm 0.05^{\mathrm{b}} \\
53.09 \pm 1.12^{\mathrm{a}} \\
34.96 \pm 1.64^{\mathrm{d}} \\
71.81 \pm 1.79^{\mathrm{b}} \\
52.31 \pm 2.52^{\mathrm{c}}\end{array}$ & $\begin{array}{c}6.60 \pm 0.03^{\mathrm{b}} \\
51.78 \pm 1.53^{\mathrm{b}} \\
35.11 \pm 1.89^{\mathrm{cd}} \\
71.91 \pm 1.88^{\mathrm{b}} \\
54.12 \pm 2.89^{\mathrm{c}}\end{array}$ & $\begin{array}{r}6.50 \pm 0.03^{\mathrm{b}} \\
53.97 \pm 1.50^{\mathrm{a}} \\
35.34 \pm 1.83^{\mathrm{c}} \\
66.38 \pm 1.92^{\mathrm{c}} \\
54.59 \pm 1.95^{\mathrm{c}}\end{array}$ & $\begin{array}{r}6.50 \pm 0.04^{\mathrm{b}} \\
46.26 \pm 1.15^{\mathrm{c}} \\
39.47 \pm 1.92^{\mathrm{b}} \\
74.56 \pm 2.08^{\mathrm{a}} \\
61.68 \pm 2.68^{\mathrm{b}}\end{array}$ & $\begin{array}{c}5.71 \pm 0.00 \\
\mathrm{ND} \\
6.20 \pm 2.78 \\
27.19 \pm 3.35 \\
14.82 \pm 2.33\end{array}$ \\
\hline $\begin{array}{l}\text { Color } \\
\mathrm{L}^{*} \text { (Luminance) } \\
\mathrm{a}^{*} \text { (Redness) } \\
\mathrm{b}^{*} \text { (Yellowness) }\end{array}$ & $\begin{array}{r}32.48 \pm 2.46^{\mathrm{c}} \\
19.7 \pm 1.75^{\mathrm{d}} \\
6.12 \mathrm{~d} \pm 0.96^{\mathrm{c}}\end{array}$ & $\begin{array}{c}34.6 \pm 2.53^{\mathrm{c}} \\
20.77 \pm 1.40^{\mathrm{cd}} \\
6.27 \pm 1.27^{\mathrm{c}}\end{array}$ & $\begin{array}{r}39.03 \pm 2.39^{\mathrm{b}} \\
21.39 \pm 1.35^{\mathrm{bc}} \\
6.42 \pm 1.42^{\mathrm{bc}}\end{array}$ & $\begin{array}{r}39.57 \pm 2.25^{\mathrm{b}} \\
22.48 \pm 1.46^{\mathrm{ab}} \\
7.87 \pm 1.12^{\mathrm{ab}}\end{array}$ & $\begin{array}{r}42.97 \pm 2.22^{\mathrm{a}} \\
23.12 \pm 1.08^{\mathrm{a}} \\
8.01 \pm 1.55^{\mathrm{a}}\end{array}$ & $\begin{array}{r}37.72 \pm 3.97 \\
6.42 \pm 1.91 \\
8.06 \pm 2.23\end{array}$ \\
\hline $\begin{array}{l}\text { Proximate (\%) } \\
\text { Moisture } \\
\text { Dry matter } \\
\text { Ash + Crude carbohydrate } \\
\text { Crude protein } \\
\text { Crude fat }\end{array}$ & $\begin{array}{r}73.28 \pm 1.05^{\mathrm{c}} \\
26.72 \pm 2.51^{\mathrm{a}} \\
3.62 \pm 0.23^{\mathrm{b}} \\
19.90 \pm 1.34^{\mathrm{a}} \\
3.20 \pm 0.94^{\mathrm{a}}\end{array}$ & $\begin{array}{c}74.54 \pm 1.48^{\mathrm{bc}} \\
25.46 \pm 2.55^{\mathrm{ab}} \\
1.96 \pm 0.15^{\mathrm{c}} \\
19.70 \pm 1.23^{\mathrm{a}} \\
3.80 \pm 0.88^{\mathrm{a}}\end{array}$ & $\begin{array}{c}73.81 \pm 1.42^{\mathrm{c}} \\
26.19 \pm 2.19^{\mathrm{a}} \\
3.99 \pm 0.49^{\mathrm{b}} \\
18.90 \pm 1.23^{\mathrm{ab}} \\
3.30 \pm 0.62^{\mathrm{a}}\end{array}$ & $\begin{array}{r}76.78 \pm 1.22^{\mathrm{ab}} \\
23.22 \pm 2.21^{\mathrm{b}} \\
1.02 \pm 0.22^{\mathrm{c}} \\
19.70 \pm 1.34^{\mathrm{a}} \\
2.50 \pm 0.49^{\mathrm{b}}\end{array}$ & $\begin{aligned} 73.44 \pm 1.32^{\mathrm{c}} \\
26.56 \pm 2.65^{\mathrm{a}} \\
7.36 \pm 0.54^{\mathrm{a}} \\
16.60 \pm 1.21^{\mathrm{b}} \\
2.60 \pm 0.51^{\mathrm{b}}\end{aligned}$ & $\begin{array}{c}73.80 \pm 0.62 \\
\text { ND } \\
\text { ND } \\
21.53 \pm 1.14 \\
1.88 \pm 0.08\end{array}$ \\
\hline
\end{tabular}

All data are expressed as mean \pm SEM of five replicates. Different superscript lowercase letters denote significant differences between different experimental groups $(p<0.05)$. The value for ash + crude carbohydrate is obtained from the deduction of the values of moisture, crude protein, and crude fat. "Literature [21]: Beef sample of a 48-month-old cattle of 300 kg BW. ND: not determined; BW: body weight.

supplemented cattle were significantly higher than the control cattle $(p<0.05)$. Also, the beef samples of selenium-fed cattle had significantly lower water loss and shear force values than the control cattle $(p<0.05)$.

Although selenium fed to the cattle improved the beef quality, the changes in physicochemical properties of the beef samples were not dose dependent. The beef samples of cattle fed with the highest selenium concentration $(1.2 \mathrm{mg} / \mathrm{kg})$ did not have the most improved physicochemical quality. Moreover, the cooked selenium-enriched beef samples had a cook loss rate higher than the water holding capacity. The reduced shear force value of the selenium-enriched beef sample showed that selenium indirectly modified the structure of boiled beef. The selenium-supplemented cattle produced beef muscles with significantly higher colour values than the control cattle $(p<0.05)$. Based on the data obtained, we can conclude that selenium-enriched beef has better physicochemical characteristics than low-selenium beef.

$\mathrm{pH}$ is one of the essential indicators for beef freshness. The $\mathrm{pH}$ values of fresh meats ranged between 5.8-6.8. By knowing the $\mathrm{pH}$ value of the meat sample, the meat quality can be effectively maintained. In this study, the $\mathrm{pH}$ values of beef samples obtained from each experimental group were within the normal range. The result showed that dietary selenium reduced the $\mathrm{pH}$ value of beef samples by 0.3 . The lower $\mathrm{pH}$ of selenium-enriched beef samples could be due to the increasing rate of glycogen breaking down to glucose, as selenium was found to be indirectly involved in glycogenolysis [22].

As shown in Table 3, the shear force values of the high selenium beef samples were significantly lower than those of the low selenium beef sample $(p<0.05)$. On the contrary, high beef selenium content increased beef hardness; and it was found from a consumer survey that higher beef tenderness, a key indicator of its quality, had a higher consumer 
acceptance [23]. Beef tenderness is related to the hardness and chewiness of the beef samples [24]. The tenderness is more accurate to be determined by shear force value, and might be affected by the moisture content of the beef sample. In this study, beef samples of the selenized yeast-fed cattle were significantly lower in water loss rate and higher in the water holding capacity and cook loss rate when compared with the control $(p<0.05)$. The results indicated that the selenized yeast effectively improved the tenderness and, hence, increased the overall acceptability of the beef.

Beef color indicators, such as luminance $\left(\mathrm{L}^{*}\right)$, redness $\left(\mathrm{a}^{*}\right)$, and yellowness $\left(\mathrm{b}^{*}\right)$, are the visible characteristics of beef quality. In this study, the beef samples of the cattle fed with a seleniumenriched diet had significantly higher $\mathrm{L}^{*}, \mathrm{a}^{*}$, and $\mathrm{b}^{*}$ values than the beef samples of the control group $(p<0.05)$. Also, the increment in color values of the beef samples was selenium concentration dependent. The bright red of the beef samples was one of the indicators for meat freshness. The high red hue of fresh meat could be due to the high level of oxymyoglobin in the meat [25]. Also, a* values of the selenium-enriched beef samples were beef selenium concentration dependent. It indicates that the high selenium level increases the freshness of the beef samples. Moreover, selenium acted as an antioxidant by scavenging free radicals in the beef muscles.

On the contrary, literature shows that organic selenium supplementation to Hanwoo steers did not affect the beef colors [26]. Another study also reported that the source of selenium did not significantly affect cook loss and sensory quality of the cooked pork $(p>0.05)$ [27]. Selenium is an antioxidant in cells that reduces water loss by improving tissue antioxidant capacity. It also maintains the integrity of the cell membrane structure and function. The increased selenium deposition in the muscle tissues of cattle attributes to the higher antioxidant status of the cattle.

A previous study reported selected physicochemical parameters of a beef sample of Xinjiang brown cattle purchased from a cattle farm in Xinjiang, China [21]. The $\mathrm{pH}$ value, water loss, cook loss rate, shear force, and a* value of the beef sample reported in the literature were lower than the values of beef samples from the control group presented in this study. These findings showed that the cattle grown in Southern China had better beef quality than the cattle of the Xinjiang region. Different geographical locations might affect the physicochemical quality of beef samples [28].

\section{Effect of different selenium doses on the proximate composition of beef samples}

As shown in Table 3, the selenium-enriched diet given to the experimental cattle did not significantly affect the proximate composition of the beef samples $(p>0.05)$. Except for the crude fat content, no significant change in the moisture, dry matter, crude protein, and ash + crude carbohydrate was found in the beef samples of the supplementation groups compared with the control group $(p>0.05)$.

The result showed that beef samples of the experimental cattle from groups $C$ and D had significantly lower crude fat content than the other groups $(p<0.05)$ indicating that the selenium-enriched diet could contribute to weight loss or reduce fat accumulation in the longissimus dorsi muscle of the cattle supplemented with a high amount of selenium. The result also showed that the moisture content of group C beef sample was significantly higher than the other supplementation groups including the control group $(p<0.05)$. Moreover, the crude protein content of the beef sample of the cattle supplemented with the highest dose of selenium (group D) was the significantly lowest compared with the beef samples from the cattle from other experimental groups $(p<0.05)$. The finding of this study showed that the selenium-enriched diet lowered the crude protein content in the beef samples.

Literature showed that the meat samples of yak (B. grunniens) grown at different altitudes of China had a variable fat content [29]. As stated in a previous report, the beef samples of Xinjiang brown cattle obtained from the farm in Xinjiang Province of China had crude fat and crude protein contents of $1.88 \%$ and $21.53 \%$, respectively [21]. The reported percentages of crude fat and crude protein were respectively lower and higher than the values obtained from this study (Table 3). Therefore, the cattle grown in different geographical regions have different beef quality.

\section{Effect of different selenium doses on amino acid composition of beef samples}

Amino acid composition (\%) of the beef samples is shown in Table 4. The result showed that the percentages of most of the beef sample amino acids were not significantly different between the experimental groups $(p>0.05)$. The amino acids were Thr, Ser, Tyr, Lys, Pro, Arg, Gly, Ala, and Ile. The group D cattle supplemented with the highest concentration of selenized yeast $(1.2 \mathrm{mg} / \mathrm{kg} \mathrm{BW})$ had 
Table 4 Effects of diet with different selenium doses on amino acid contents (\%) of the Xinjiang brown cattle beef.

\begin{tabular}{|c|c|c|c|c|c|}
\hline Amino acid & CG & A & B & $\mathrm{C}$ & $\mathrm{D}$ \\
\hline Ala & $1.10 \pm 0.04^{\mathrm{a}}$ & $1.17 \pm 0.05^{\mathrm{a}}$ & $1.10 \pm 0.06^{\mathrm{a}}$ & $1.08 \pm 0.03^{\mathrm{a}}$ & $1.16 \pm 0.03^{a}$ \\
\hline Arg & $1.13 \pm 0.02^{\mathrm{a}}$ & $1.14 \pm 0.04^{\mathrm{a}}$ & $1.14 \pm 0.05^{\mathrm{a}}$ & $1.17 \pm 0.04^{\mathrm{a}}$ & $1.26 \pm 0.05^{\mathrm{a}}$ \\
\hline Asp & $1.75 \pm 0.04^{\mathrm{c}}$ & $1.85 \pm 0.03^{\mathrm{ab}}$ & $1.80 \pm 0.02^{b c}$ & $1.81 \pm 0.03^{\mathrm{bc}}$ & $1.91 \pm 0.02^{\mathrm{a}}$ \\
\hline Glu & $3.02 \pm 0.02^{\mathrm{c}}$ & $3.05 \pm 0.05^{\mathrm{b}}$ & $2.92 \pm 0.06^{\mathrm{d}}$ & $2.93 \pm 0.03^{\mathrm{d}}$ & $3.17 \pm 0.05^{a}$ \\
\hline Gly & $0.78 \pm 0.05^{\mathrm{a}}$ & $0.82 \pm 0.05^{\mathrm{a}}$ & $0.78 \pm 0.06^{\mathrm{a}}$ & $0.75 \pm 0.05^{a}$ & $0.83 \pm 0.04^{\mathrm{a}}$ \\
\hline His & $0.70 \pm 0.05^{c}$ & $0.80 \pm 0.03^{\mathrm{a}}$ & $0.76 \pm 0.06^{b}$ & $0.65 \pm 0.01^{\mathrm{e}}$ & $0.68 \pm 0.02^{\mathrm{d}}$ \\
\hline Ile & $0.77 \pm 0.02^{\mathrm{a}}$ & $0.85 \pm 0.01^{\mathrm{a}}$ & $0.82 \pm 0.05^{\mathrm{a}}$ & $0.72 \pm 0.03^{\mathrm{a}}$ & $0.90 \pm 0.06^{\mathrm{a}}$ \\
\hline Leu & $1.51 \pm 0.03^{\mathrm{d}}$ & $1.60 \pm 0.03^{b}$ & $1.52 \pm 0.02^{\mathrm{cd}}$ & $1.53 \pm 0.01^{\mathrm{c}}$ & $1.67 \pm 0.02^{\mathrm{a}}$ \\
\hline Lys & $1.71 \pm 0.02^{\mathrm{a}}$ & $1.81 \pm 0.03^{\mathrm{a}}$ & $1.72 \pm 0.03^{\mathrm{a}}$ & $1.71 \pm 0.02^{\mathrm{a}}$ & $1.86 \pm 0.02^{\mathrm{a}}$ \\
\hline Met & $0.48 \pm 0.01^{\mathrm{c}}$ & $0.49 \pm 0.01^{\mathrm{c}}$ & $0.53 \pm 0.02^{b}$ & $0.53 \pm 0.01^{b}$ & $0.57 \pm 0.02^{\mathrm{a}}$ \\
\hline Phe & $0.78 \pm 0.02^{\mathrm{d}}$ & $0.86 \pm 0.01^{a}$ & $0.82 \pm 0.02^{c}$ & $0.78 \pm 0.02^{\mathrm{d}}$ & $0.84 \pm 0.01^{b}$ \\
\hline Pro & $0.56 \pm 0.02^{\mathrm{a}}$ & $0.58 \pm 0.02^{\mathrm{a}}$ & $0.54 \pm 0.01^{\mathrm{a}}$ & $0.54 \pm 0.02^{\mathrm{a}}$ & $0.56 \pm 0.02^{a}$ \\
\hline Ser & $0.80 \pm 0.02^{\mathrm{a}}$ & $0.83 \pm 0.02^{\mathrm{a}}$ & $0.78 \pm 0.03^{a}$ & $0.79 \pm 0.02^{\mathrm{a}}$ & $0.83 \pm 0.02^{\mathrm{a}}$ \\
\hline Thr & $0.93 \pm 0.01^{\mathrm{a}}$ & $1.00 \pm 0.01^{\mathrm{a}}$ & $0.94 \pm 0.02^{\mathrm{a}}$ & $0.94 \pm 0.02^{\mathrm{a}}$ & $0.98 \pm 0.02^{\mathrm{a}}$ \\
\hline Tyr & $0.72 \pm 0.01^{\mathrm{a}}$ & $0.76 \pm 0.01^{\mathrm{a}}$ & $0.73 \pm 0.01^{\mathrm{a}}$ & $0.70 \pm 0.01^{\mathrm{a}}$ & $0.74 \pm 0.01^{\mathrm{a}}$ \\
\hline Val & $0.81 \pm 0.03^{\mathrm{d}}$ & $0.89 \pm 0.02^{\mathrm{b}}$ & $0.85 \pm 0.03^{c}$ & $0.77 \pm 0.03^{\mathrm{e}}$ & $0.92 \pm 0.02^{\mathrm{a}}$ \\
\hline TAAs & $17.55 \pm 0.75^{d}$ & $18.50 \pm 0.84^{b}$ & $17.75 \pm 0.70^{c}$ & $17.40 \pm 0.73^{\mathrm{e}}$ & $18.88 \pm 0.85^{a}$ \\
\hline EAAs & $6.99 \pm 0.34^{\mathrm{d}}$ & $7.50 \pm 0.36^{b}$ & $7.20 \pm 0.23^{c}$ & $6.98 \pm 0.44^{\mathrm{e}}$ & $7.74 \pm 0.63^{a}$ \\
\hline EAAs/TAAs & $0.40 \pm 0.08^{a}$ & $0.41 \pm 0.07^{\mathrm{a}}$ & $0.41 \pm 0.05^{\mathrm{a}}$ & $0.40 \pm 0.05^{\mathrm{a}}$ & $0.41 \pm 0.06^{\mathrm{a}}$ \\
\hline UAAs & $9.41 \pm 0.11^{\mathrm{ab}}$ & $9.86 \pm 0.12^{\mathrm{a}}$ & $9.44 \pm 0.46^{b}$ & $9.31 \pm 0.13^{\mathrm{b}}$ & $10.15 \pm 0.12^{\mathrm{a}}$ \\
\hline UAAs/TAAs & $0.54 \pm 0.02^{\mathrm{a}}$ & $0.53 \pm 0.08^{a}$ & $0.53 \pm 0.02^{\mathrm{a}}$ & $0.54 \pm 0.01^{\mathrm{a}}$ & $0.54 \pm 0.08^{a}$ \\
\hline
\end{tabular}

All data are expressed as mean \pm SEM (\%) of five replicates. Different superscript lowercase letters denote significant differences between different experimental groups at $p<0.05$. Essential amino acids include histidine (His), isoleucine (Ile), leucine (Leu), lysine (Lys), methionine (Met), phenylalanine (Phe), threonine (Thr), and valine (Val); umami-taste amino acids are glutamate (Glu), aspartic acid (Asp), serine (Ser), glycine (Gly), isoleucine (Ile), leucine (Leu), and phenylalanine (Phe). The other amino acids are tyrosine (Try), proline (Pro), arginine (Arg), and alanine (Ala). TAA: Total amino acids; EAA: Essential amino acids; UAA: Umami-taste amino acids.

the significantly highest levels of Asp, Glu, Leu, Met, Phe, and Val compared with the other experimental groups $(p<0.05)$. Three out of the five amino acids are essential for the human body. Asparagine (Asn), cysteine (Cys), glutamine (Gln), and tryptophan (Trp) were not determined in this study. It is due to the laboratory protocol that only allowed the determination of 16 amino acids (Table 4). The supplementation with selenized yeast somehow increased the Phe level compared with negative control.

On the contrary, supplementation of the cattle with high doses (0.9 and $1.2 \mathrm{mg} / \mathrm{kg} \mathrm{BW}$ ) of selenized yeast contributed to a significant decreased in the level of histidine $(p<0.05)$. The beef sample of group D cattle contained the significantly highest levels of Asp and Glu $(p<0.05)$. However, these amino acids are non-essential amino acids. They are synthesized in the liver. Therefore, the increased level of these amino acids is not meaningful. Among the amino acids with sensory taste, the levels of Leu and Val (bitter taste) in the beef samples of the cattle supplemented with the highest dose of selenized yeast were significantly higher than the negative control $(p<0.05)$. The supplementation did not affect the sweet taste amino acids (Ala and Gly). According to the previous studies, L-glutamate (Glu) is one of the amino acids that gives umami taste $[30,31]$.
Protein is one of the main components that attributed to the nutritional quality of beef. Amino acids are the basic unit of protein; the content and proportion of the amino acids in beef muscle are the indicators for the nutritional value of a beef [32]. They contribute to the taste of beef, especially the sweet, bitter, and umami-taste amino acids. Glu is unique due to its umami taste, having a meaty flavor and salty taste. The significant increase of Glu in the beef samples from the cattle that received the highest amount of selenized yeast attribute to the flavor of the beef. Literature also showed that adding selenium and germanium enriched yeast culture to the cattle feed increased the amounts of lysine, alanine, and glutamic acid in Yanbian yellow cattle's muscles and improved the flavor of beef [33].

\section{Effect of different selenium levels on fatty acid composition of beef samples}

The fatty acid composition of the beef samples is tabulated as in Table 5 and Fig. S1. The results showed that the percentages of myristic acid, palmitic acid, margaric acid, stearic acid, oleic acid, and linoleic acid of the beef samples were significantly different between the experimental groups $(p<0.05)$. The percentages of linolenic acid, arachidic acid, and arachidonic acid between the experimental cattle 
Table 5 Effects of diets with different selenium doses on fatty acids content (\%) of the Xinjiang brown cattle beef.

\begin{tabular}{|c|c|c|c|c|c|c|c|}
\hline Peak & Fatty acid & Carbon chain & CG & A & B & $\mathrm{C}$ & $\mathrm{D}$ \\
\hline 1 & Myristic acid & C14:0 & $2.53 \pm 0.06^{c}$ & $2.26 \pm 0.05^{\mathrm{d}}$ & $3.88 \pm 0.08^{a}$ & $2.26 \pm 0.05^{\mathrm{d}}$ & $3.01 \pm 0.06^{\mathrm{b}}$ \\
\hline 2 & Palmitic acid & C16:0 & $22.6 \pm 0.05^{c}$ & $21.6 \pm 0.05^{d}$ & $25.2 \pm 0.06^{\mathrm{a}}$ & $21.6 \pm 0.04^{d}$ & $24.1 \pm 0.04^{b}$ \\
\hline 3 & Margaric acid & C17:0 & $1.43 \pm 0.04^{b}$ & $1.23 \pm 0.04^{\mathrm{c}}$ & $0.96 \pm 0.01^{\mathrm{d}}$ & $1.23 \pm 0.02^{\mathrm{c}}$ & $1.53 \pm 0.02^{\mathrm{a}}$ \\
\hline 4 & Stearic acid & C18:0 & $24.6 \pm 0.05^{a}$ & $18.6 \pm 0.06^{c}$ & $16.5 \pm 0.03^{\mathrm{d}}$ & $18.6 \pm 0.04^{c}$ & $20.4 \pm 0.06^{\mathrm{b}}$ \\
\hline 5 & Oleic acid & C18:1 & $37.1 \pm 0.04^{c}$ & $42.2 \pm 0.04^{\mathrm{a}}$ & $37.8 \pm 0.05^{b}$ & $42.2 \pm 0.06^{\mathrm{a}}$ & $28.5 \pm 0.04^{\mathrm{d}}$ \\
\hline 6 & Linoleic acid & C18:2 (n-6) & $2.27 \pm 0.05^{b}$ & $2.41 \pm 0.05^{\mathrm{a}}$ & $2.41 \pm 0.04^{\mathrm{a}}$ & $2.15 \pm 0.05^{c}$ & $1.89 \pm 0.06^{\mathrm{d}}$ \\
\hline 7 & Linolenic acid & C18:3 (n-3) & $0.15 \pm 0.03^{a}$ & $0.17 \pm 0.04^{\mathrm{a}}$ & $0.23 \pm 0.05^{\mathrm{a}}$ & $0.17 \pm 0.04^{\mathrm{a}}$ & $0.15 \pm 0.05^{\mathrm{a}}$ \\
\hline 8 & Arachidic acid & C20:0 & $0.24 \pm 0.02^{\mathrm{a}}$ & $0.19 \pm 0.03^{\mathrm{a}}$ & $0.19 \pm 0.01^{\mathrm{a}}$ & $0.19 \pm 0.05^{\mathrm{a}}$ & $0.23 \pm 0.03^{\mathrm{a}}$ \\
\hline 9 & Arachidonic acid & $C 20: 4(n-6)$ & $0.27 \pm 0.03^{a}$ & $0.29 \pm 0.02^{\mathrm{a}}$ & $0.27 \pm 0.03^{a}$ & $0.29 \pm 0.04^{\mathrm{a}}$ & $0.27 \pm 0.03^{\mathrm{a}}$ \\
\hline
\end{tabular}

All data are expressed as mean \pm SEM (\%) of five replicates. Different superscript lowercase letters denote significant differences between different experimental groups $(p<0.05)$

of different groups were not significantly different $(p>0.05)$.

The finding of this study revealed that selenium supplementation did not significantly affect the polyunsaturated fatty acids (PUFAs) of the beef samples $(p>0.05)$, except for linoleic acid. As shown in Table 5 , the beef sample of group $\mathrm{D}$, the highest selenized yeast supplemented experimental cattle $(1.2 \mathrm{mg} / \mathrm{kg} \mathrm{BW})$, had the percentages of oleic acid and linoleic acid significantly lower than the beef samples from the other groups $(p<0.05)$. It showed that the high dose of selenized yeast only contributed to a minor improvement in the beef quality.

Among the saturated fatty acids (SFAs), the percentages of stearic acid in the beef samples of the selenized yeast supplemented cattle groups were significantly lower than the control group ( $p<$ 0.05). The beef sample of the group D cattle fed with the highest dose of selenized yeast had percentages of margaric acid and stearic acid significantly higher than the other groups $(p<0.05)$. On the contrary, the only long-chain SFA not affected by the selenium supplementation was arachidic acid (C20:0). Besides, the selenium supplementation did not affect the myristic acid, palmitic acid, and margaric acid contents of the beef samples. The percentages of these three SFAs of the beef samples obtained from the supplemented cattle were varied (Table 5). The beef samples from groups A and C had the significantly lowest percentages of myristic acid and palmitic acid, and the highest percentages of these two fatty acids were determined in the beef samples of group B cattle $(p<0.05)$. Also, the percentages of margaric acid were significantly the lowest in group B and significantly the highest in group D $(p<0.05)$.

Supplementation of $0.1-0.3 \%$ of selenium and germanium enriched yeast culture to the cattle diet increased the linoleic acid content of the beef sam- ples by $9.21-17.06 \%$ compared with the control group [32]. Thus, the finding supported our results that the beef samples of the cattle supplemented with low doses (0.3 and $0.6 \mathrm{mg} / \mathrm{kg} \mathrm{BW})$ of selenized yeast had a $6.17 \%$ increase in linoleic acid content compared with the control cattle. However, beef samples of the cattle supplemented with the selenized yeast of $0.9 \mathrm{mg} / \mathrm{kg} \mathrm{BW}$ or higher had a gradual decrease in linoleic acid content (Table 5).

Besides the linoleic acid, the cattle supplemented with low doses of selenized yeast (0.3$0.9 \mathrm{mg} / \mathrm{kg}$ BW) had minimal increased linolenic acid content in the muscle tissues; however, the values were not significantly different $(p>0.05)$. On the contrary, the pork from a swine-fed sodium selenite diet had a lower fatty acids content than the selenized yeast-fed swine [34]. The fatty acids were mainly monounsaturated fatty acids. It supports the result of this study that muscle tissues of the cattle supplemented with selenized yeast had a significantly higher oleic acid content than the control $(p<0.05)$.

Literature showed that intake of selenium is linked with lipid metabolism in animals [35]. Linoleic and linolenic acids are essential fatty acids for human beings. The two fatty acids are the omega- 6 and omega- 3 fatty acids, respectively; and they can only be obtained from food. The organic selenium supplementation has a significant effect on the metabolism of linoleic acid in the muscle of experimental cattle. The moderate amount of supplemented selenium, an important component in lipid metabolism [9], prevents lipid peroxidation in the muscle tissues of cattle [36], thus reduces the oxidation of PUFA.

With some exceptions, the selenium supplement reduced the level of long-chain SFAs in the beef samples. A low-dose supplementation of selenized yeast to the cattle improved the beef quality by lowering the long-chain SFAs compared with the high-dose 
supplementation. In contrast, literature reported that selenium supplementation did not alter the fatty acid compositions of the beef samples [9,37]. The addition of copper $(40 \mathrm{mg} / \mathrm{kg}$ dry matter) and selenium ( $40 \mathrm{mg} / \mathrm{kg}$ dry matter) to the bull's feeds showed significant reductions in levels of linoleic acid and palmitic acid of the beef samples [38]. The yeast's chemical components could improve the quality of beef. Besides protein and lipid, yeasts contained polysaccharides such as glucan, mannan, and chitin [39]. Therefore, the finding of this study contributes to the web of knowledge on the effect of selenium enriched diet on the prevention of lipid oxidation in muscle tissues of cattle.

\section{CONCLUSION}

The results obtained from this study prove that organic selenium played an antioxidative role in improving the quality of the beef samples. The improvement in the beef quality was achieved by the increased selenium content in the beef samples of the experimental cattle. Supplementation of selenized yeast to the experimental cattle increased the tenderness and other nutritional quality of the beef samples. This study is an initial step in producing quality and premium beef for local consumption and export. As the experimentation is limited to the Xinjiang brown cattle, future studies should compare the beef quality of different species of cattle supplemented with selenium, both organic and inorganic.

\section{Appendix A. Supplementary data}

Supplementary data associated with this article can be found at http://dx.doi.org/10.2306/ scienceasia1513-1874.2021.102.

Acknowledgements: The authors would like to acknowledge the support from the Guangxi Scientific Research and Technological Development Projects (Gui Ke AD19110141) and Foundation of Fundamental Research Project from the Guangxi Academy of Agricultural Sciences (2021YTI16).

\section{REFERENCES}

1. Liu T, Ju X, Zhang M, Wei C, Wang D, Wang Z, Lan $X$, Huang XX (2021) A 67-bp variable duplication in the promoter region of the ADIPOQ is associated with milk traits in Xinjiang brown cattle. Anim Biotechnol, 1-9.

2. Lin HK, Zhang Y, Zhou ZY, Pan JC, Zhang JS, Li HB, Yan XM, Du W, et al (2010) The principal component analysis of Xinjiang brown cattle body measurement trait. China Anim Husb Vet Med 37, 130-133.
3. Wood JD, Richardson RI, Nute GR, Fisher AV, Campo MM, Kasapidou E, Sheard PR, Enser M (2004) Effects of fatty acids on meat quality: A review. Meat Sci 66, 21-32.

4. Santos-Silva J, Bessa RJB, Santos-Silva F (2002) Effect of genotype, feeding system and slaughter weight on the quality of light lambs: II. Fatty acid composition of meat. Livest Prod Sci 77, 187-194.

5. DelCurto T, Hess BW, Huston JE, Olson KC (2000) Optimum supplementation strategies for beef cattle consuming low-quality roughages. J Anim Sci 77, $1-16$.

6. Baowei W, Guoqing H, Qiaoli W, Bin Y (2011) Effects of yeast selenium supplementation on the growth performance, meat quality, immunity, and antioxidant capacity of goose. J Anim Physiol Anim Nutr 95, 440-448.

7. Vignola G, Lambertini L, Mazzone G, Giammarco M, Tassinari M, Martelli G, Bertin G (2009) Effects of selenium source and level of supplementation on the performance and meat quality of lambs. Meat Sci 81, 678-685.

8. Surai PF (2002) Selenium in poultry nutrition 2. Reproduction, egg and meat quality and practical applications. Worlds Poult Sci J 58, 431-450.

9. Mehdi Y, Dufrasne I (2016) Selenium in cattle: A review. Molecules 21, ID 545.

10. China Animal Feeding Standards (2004) Feeding standard of beef cattle, NY/T 815-2004. Ministry of Agriculture, Beijing, People's Republic of China.

11. Xia Q, Yang ZP, Xue NW, Dai XJ, Zhang X, Gao ZQ (2019) Effect of foliar application of selenium on nutrient concentration and yield of colored-grain wheat in China. Appl Ecol Env Res 17, 2187-2202.

12. Chinese Ministry of Health (2016) Determination of Fatty Acids in Food, GB 5009.168-2016, State Food and Drug Administration, Beijing, People's Republic of China.

13. Jing LB (2015) AFS-9700 atomic fluorescence spectrometer simultaneous determination of arsenic and selenium in groundwater. Jilin Water Resour 10, 44-47.

14. Kohrle J, Jakob F, Contempre B, Dumont JE (2005) Selenium, the thyroid, and the endocrine system. Endocr Rev 26, 944-984.

15. Sgoifo Rossi CA, Compiani R, Baldi G, Muraro M, Marden JP, Rossi R, Pastorelli G, Corino C, et al (2017) Organic selenium supplementation improves growth parameters, immune and antioxidant status of newly received beef cattle. J Anim Feed Sci 26, 100-108.

16. Lawler TL, Taylor JB, Finley JW, Caton JS (2004) Effect of supranutritional and organically bound selenium on performance, carcass characteristics, and selenium distribution in finishing beef steers. $J$ Anim Sci 82, 1488-1493.

17. Mahan DC, Peters JC (2004) Long-term effects of 
dietary organic and inorganic selenium sources and levels on reproducing sows and their progeny. J Anim Sci 82, 1343-1358.

18. Arthington JD (2008) Effects of supplement type and selenium source on measures of growth and selenium status in yearling beef steers. J Anim Sci 86, 1472-1477.

19. Byers FM, Moxon AL (1980) Protein and selenium levels for growing and finishing beef cattle. $J$ Anim Sci 50, 1136-1144.

20. García-Vaquero M, Miranda M, Benedito JL, BlancoPenedo I, López-Alonso M (2011) Effect of type of muscle and $\mathrm{Cu}$ supplementation on trace element doses in cattle meat. Food Chem Toxicol 49, 1443-1449.

21. Zhao G, Qin K, Li J, Zhu C, Nai B, Liu J (2021) Differences in meat quality among different carcass parts of Xinjiang brown cattle. Meat Res 35, 1-6.

22. Taylor D, Dalton C, Hall A, Woodroofe MN, Gardiner PHE (2009) Recent developments in selenium research. Br J Biomed Sci 66, 107-116.

23. Platter WJ, Tatum JD, Belk KE, Chapman PL, Scanga JA, Smith GC (2003) Relationships of consumer sensory ratings, marbling score, and shear force value to consumer acceptance of beef strip loin steaks. J Anim Sci 81, 2741-2750.

24. Sasaki K, Motoyama M, Narita T (2012) Increased intramuscular fat improves both 'chewiness' and 'hardness' as defined in ISO5492:1992 of beef Longissimus muscle of Holstein $\times$ Japanese Black F1 steers. Anim Sci $J$ 83, 338-343.

25. Lee BJ, Hendricks DG, Cornforth DP (1998) Antioxidant effects of carnosine and phytic acid in a model beef system. J Food Sci 63, 394-398.

26. Park BY, Cho SH, Seong PN, Kim JH, Kang GH, Lee SH, Kim WY, Lee JM, et al (2009) Effect of selenium supplementation on beef color stability. Food Sci Anim Res 29, 627-632.

27. Castro-Ríos K, Narvaéz-Solarte W (2013) Sensory quality and cooking loss in pork meat: effect of sex and source of selenium. Biotecnol Sector Agropecuario Agroind 11, 130-135.

28. Delgado EJ, Rubio MS, Iturbe FA, Méndez RD, Cassís L, Rosiles R (2005) Composition and quality of Mexican and imported retail beef in Mexico. Meat Sci 69, 465-471.
29. Nie J, Shao S, Xia W, Liu Z, Yu C, Li R, Wang W, Li $\mathrm{J}$, et al (2020) Stable isotopes verify geographical origin of yak meat from Qinghai-Tibet plateau. Meat Sci 165, ID 108113.

30. Wu X, Xu P, Wu X, Wang B, Lu Z, Li G (2017) Genomewide association analysis of free glutamate content, a key factor conferring umami taste in the bottle gourd [Lagenaria siceraria (Mol.) Standl.]. Sci Hortic 225, 795-801.

31. Suzuki H (2019) Bacterial $\gamma$-glutamyltranspeptidase: Food and medicinal applications. ScienceAsia 45, 503-508.

32. Scollan N, Hocquette JF, Nuernberg K, Dannenberger D, Richardson I, Moloney A (2006) Innovations in beef production systems that enhance the nutritional and health value of beef lipids and their relationship with meat quality. Meat Sci 74, 17-33.

33. Han D, Geng C, Zhang M (2018) Effects of yeast culture with selenium and germanium on growth performance, fatty acid and amino acid contents in muscle of Yanbian yellow cattle. Chinese J Anim Nutr 30, 2850-2856.

34. Calvo L, Segura J, Toldrá F, Flores M, Rodríguez AI, López-Bote CJ, Rey AI (2017) Meat quality, free fatty acid concentration, and oxidative stability of pork from animals fed diets containing different sources of selenium. Food Sci Technol Int 23, 716-728.

35. Steinbrenner $H$ (2013) Interference of selenium and selenoproteins with the insulin-regulated carbohydrate and lipid metabolism. Free Radic Biol Med 65, 1538-1547.

36. Webb EC (2006) Manipulating beef quality through feeding. S Afr J Food Sci Nutr 7, 5-15.

37. Pereira ASC, Santos MVD, Aferri G, Corte RRPDS, De Freitas Júnior JE, Leme PR, Rennó FP (2012) Lipid and selenium sources on fatty acid composition of intramuscular fat and muscle selenium concentration of Nellore steers. Rev Bras Zootec 41, 2357-2363.

38. Netto AS, Zanetti MA, Del Claro GR, de Melo MP, Vilela FG, Correa LB (2014) Effects of copper and selenium supplementation on performance and lipid metabolism in confined brangus bulls. Asianaustralas J Anin Sci 27, 488-494.

39. Korolenko TA, Bgatova NP, Vetvicka V (2019) Glucan and mannan-two peas in a pod. Int $J$ Mol Sci 20, ID 3189. 


\section{Appendix A. Supplementary data}

Table S1 Dietary composition and nutrition level of cattle feed.

\begin{tabular}{lrlr}
\hline Ingredient & $(\%)$ & Nutrient content & 17.66 \\
\hline Corn & 42 & Crude protein (\%) & 2.89 \\
Soybean meal & 28 & Crude fat (\%) & 0.91 \\
Wheat bran & 5 & Ca (\%) & 0.51 \\
Jujube powder & 20 & P (\%) & 71.97 \\
Premix & 5 & Total digestible nutrient (\%) & 9.21 \\
Total & 100 & Digestible protein (\%) & 1.75 \\
& & Net energy (MCal $/ \mathrm{kg})$ & \\
\hline
\end{tabular}

" Per kg of the premix containing $100000 \mathrm{IU}$ of vitamin $\mathrm{D}_{3}, 700 \mathrm{mg}$ of vitamin E, $224000 \mathrm{IU}$ of vitamin A, $1900 \mathrm{mg}$ of $\mathrm{Zn}, \mathrm{Mn}$ of $1200 \mathrm{mg}, 160 \mathrm{~g}$ of $\mathrm{NaCl}, 200 \mathrm{~g}$ of $\mathrm{Ca}$, and $40 \mathrm{~g}$ of $\mathrm{P}$.

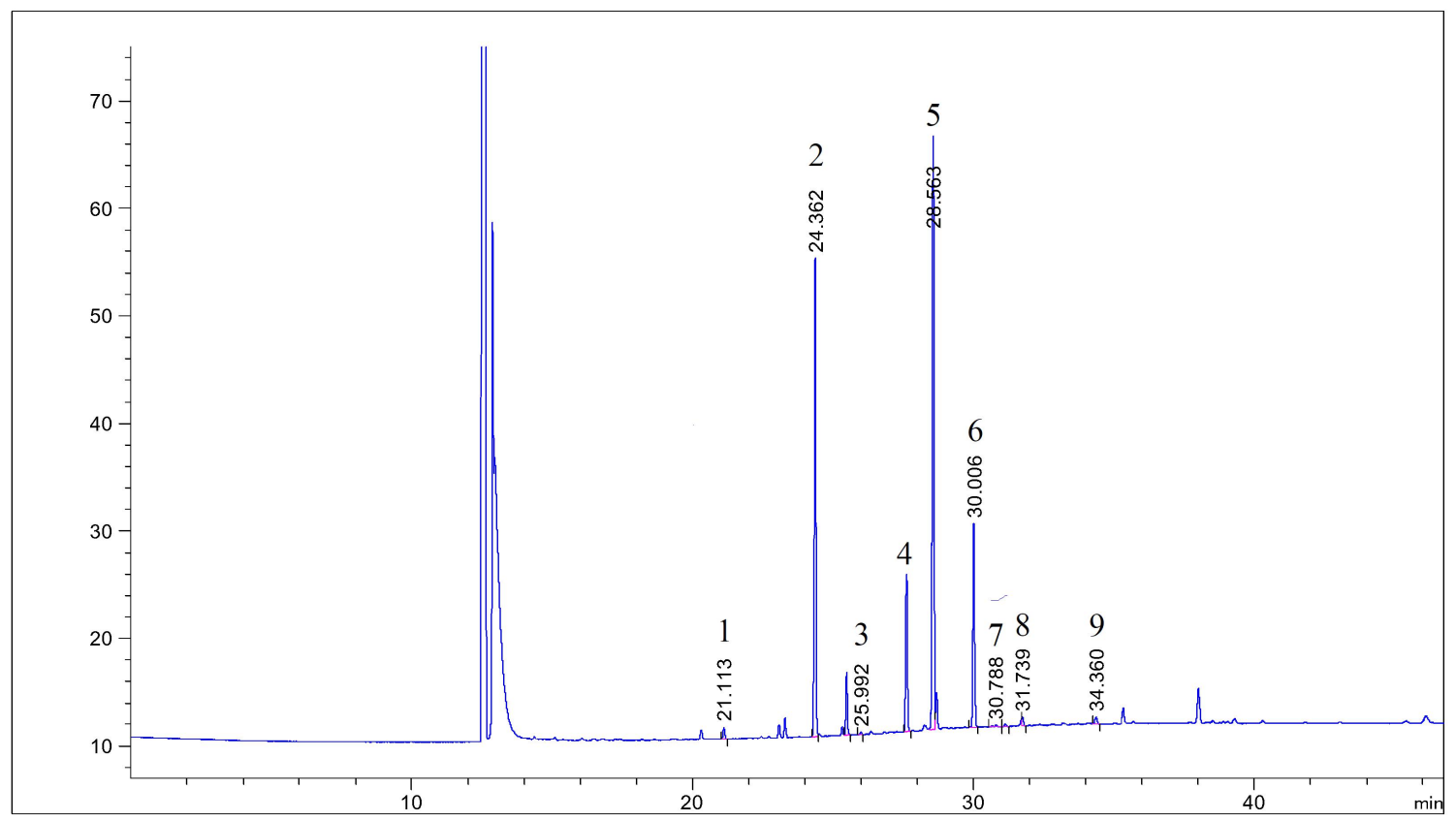

Fig. S1 HPLC chromatogram of fatty acids in beef samples. 